\title{
PENGARUH PEMBERDAYAAN PSIKOLOGIS DAN BUDAYA ORGANISASI TERHADAP PERILAKU INOVATIF
}

\author{
I Gusti Ayu Sastria Taradita ${ }^{1}$ \\ I Made Artha Wibawa ${ }^{2}$ \\ ${ }^{1}$ Fakultas Ekonomi dan Bisnis Universitas Udayana (Unud), Bali, Indonesia \\ email:sastrya62@gmail.com
}

\begin{abstract}
ABSTRAK
Penelitian ini bertujuan untuk menjelaskan 1) pengaruh pemberdayaan psikologis terhadap perilaku inovatif, 2) pengaruh budaya organisasi terhadap perilaku inovatif. Penelitian ini dilakukan di UD Romo Jewelry Manufacture. Jumlah sampel yang diambil sebanyak 72 orang karyawan, dengan metode non probabilitas sampling dengan jenis teknik sampling jenuh. Pengumpulan data dilakukan melalui pendekatan survey dengan metode kuesioner dan wawancara. Teknik analisis yang digunakan adalah regresi linier berganda. Berdasarkan hasil analisis ditemukan bahwa pemberdayaan psikologis dan budaya organisasi secara simultan berpengaruh positif dan signifikan terhadap perilaku inovatif. Hal ini menunjukkan bahwa semakin tinggi pemberdayaan psikologis yang diberikan kepada karyawan maka semakin tinggi juga perilaku inovatif karyawan. Begitu pula dengan budaya organisasi, semakin tinggi budaya organisasi pada suatu perusahaan maka semakin tinggi juga perilaku inovatif karyawan. Oleh karena itu untuk menumbuhkan perilaku inovatif pada karyawan perusahaan diharapkan lebih memperhatikan pemberdayaan psikologis dan budaya organisasi agar dapat meningkatkan perilaku inovatif.
\end{abstract}

Kata Kunci : pemberdayaan psikologis, budaya organisasi, perilaku inovatif

\begin{abstract}
This study aims to explain 1) the effect of psychological empowerment on innovative behavior, 2) the influence of organizational culture on innovative behavior. This research was conducted at UD Romo Jewelry Manufacture. The number of samples taken was 72 employees, with a non probability sampling method with a type of saturated sampling technique. Data collection is done through a survey approach with questionnaire and interview methods. The analysis technique used is multiple linear regression. Based on the results of the analysis it was found that psychological empowerment and organizational culture simultaneously had a positive and significant effect on innovative behavior. This shows that the higher the psychological empowerment given to employees, the higher the employee's innovative behavior. Likewise with organizational culture, the higher the organizational culture of a company, the higher the employee's innovative behavior. Therefore to foster innovative behavior in company employees is expected to pay more attention to psychological empowerment and organizational culture in order to improve innovative behavior.
\end{abstract}

Keywords: psychological empowerment, organizational culture, innovative behavior 
I Gusti Ayu Sastria Taradita, Pengaruh Pemberdayaan Psikologis...

\section{PENDAHULUAN}

Di dunia bisnis saat ini, mencapai keunggulan kompetitif sangat penting bagi organisasi untuk menghadapi persaingan antar organisasi yang semakin ketat. Keberhasilan Organisasi dalam menciptakan keunggulan kompetitif sangat terkait dengan sumber daya organisasi yang menjadi faktor penentu dari keberadaan serta peranannya yang memberikan konstribusi secara efektif dan efisien terhadap pencapaian tujuan organisasi (Manoela, 2013). Keunggulan kompetitif itu sendiri dapat dicapai dengan cara meningkatkan perilaku inovatif sumber daya manusia atau karyawan yang berada dalam suatu organisasi karena dengan adanya perilaku inovatif dari seorang karyawan akan sangat mempengaruhi dan berdampak baik bagi kinerja perusahaan.

Selain itu, permasalahan pasti akan timbul sehingga perusahaan diharapkan dapat mengatasinya. Sebuah organisasi harus memiliki perspektif yang berbeda dalam menyelesaikan masalah ketika solusi sebelumnya tidak berfungsi. Kemampuan menghasilkan solusi bergantung pada kreativitas berpikir dan berinovasi dari anggota organisasi, maka daripada itu inovasi merupakan bentuk kreativitas yang dibuat oleh organisasi dan digunakan untuk keuntungan organisasi itu sendiri sehingga membawa organisasi ke jalan yang lebih baik (Yildiz et al., 2017).

Perilaku sumber daya manusia merupakan salah satu faktor penting dalam organisasi, karena melalui sumber daya manusia, sumber daya yang lain dalam organisasi dapat berfungsi dan berjalan (Kwistianus dan Devie, 2015). Bandura (1989) berpendapat bahwa seorang karyawan akan mengalami proses 
pembelajaran dengan cara mengamati orang lain atau rekan kerjanya dalam melakukan suatu kegiatan atau pekerjaan, proses pembelajaran tersebut disebut sebagai teori sosial kognitif, maka dari itu teori tersebut melandasi perilaku inovatif karyawan. Menurut Afsar dan Badir (2016) salah satu pilihan atau cara bagi organisasi untuk menjadi lebih inovatif dan sukses adalah dengan mendorong karyawan mereka untuk menampilkan perilaku kerja inovatif.

Perilaku kerja inovatif didefinisikan sebagai bentuk perilaku yang bertujuan mencapai inisiasi dan pengenalan suatu ide, proses, prosedur maupun produk baru yang berguna bagi organisas (Wardhani dan Gulo, 2017). Perilaku inovatif juga dapat diartikan sebagai keseluruhan tindakan individu yang mengarah pada pemunculan, pengenalan, dan penerapan dari sesuatu yang baru dan menguntungkan bagi organisasi (Logahan et al., 2014). Sedangkan menurut Novianti dan Nurtjahjanti (2018) perilaku inovatif adalah keseluruhan tindakan individu yang mengarah pada pemunculan, pengenalan, dan penerapan dari sesuatu yang baru guna memberi keuntungan di seluruh tingkat organisasi.

Perilaku inovatif didefinisikan sebagai tindakan individu untuk menciptakan dan mengadopsi ide-ide, pemikiran atau cara-cara baru guna diterapkan dalam pelaksanaan dan penyelesain pekerjaan (Gaynor, 2002). Perilaku inovatif pada dasarnya merupakan kemampuan individu melakukan perubahan cara kerja dalam bentuk mengadopsi prosedur, praktek dan teknik kerja yang baru dalam menyelesaikan tugas dan pekerjaanya (Price, 1997). Perilaku inovatif dapat didefinisikan sebagai perilaku yang mempengaruhi seseorang untuk memikirkan ide yang tidak biasa, baik dalam prosedur atau produk dalam organisasi apa pun 
I Gusti Ayu Sastria Taradita, Pengaruh Pemberdayaan Psikologis...

(Van der Vegt dan Janssen, 2003). Untuk mencapai perilaku kerja yang inovatif pada karyawan, manajer atau organisasi harus menganggap bahwa karyawan bukan merupakan salah satu item pengeluaran, namun sebaliknya, mereka memiliki efek mengurangi pada semua item biaya lainnya (Yildiz et al., 2017).

Bali merupakan salah satu Provinsi yang berada di Indonesia dengan berbagai keanekaragaman budaya. Salah satu budaya kesenian Bali adalah kerajinan perhiasan emas dan perak yang berada di desa Celuk, kecamatan Gianyar. Kerajinan perhiasan emas dan perak Bali sangat terkenal sampai ke luar negeri dan telah banyak pengusaha industri tersebut menjalankan bisnis eksport. Namun persaingan sangat ketat sehingga usaha industri emas dan perak yang berada di desa Celuk dituntut untuk terus meningkatkan kinerja demi menjaga persaingan dan mencapai keunggulan kompetitif. Maka dari itu diperlukan adanya partisipasi dari karyawan dengan menumbuhkan perilaku inovatif sehingga diharapkan usaha industri kerajinan emas dan perak desa Celuk dapat terus maju dan bersaing.

Usaha Dagang Romo Jewelry Manufacture atau UD Romo Jewelry Manufacture merupakan usaha yang bergerak dalam bidang produksi industri dan perdagangan kerajinan perhiasan perak dan emas. Usaha yang didirikan oleh I Kadek Mustika tersebut bernama Romo karena nama panggilan dari pendirinya adalah I Kadek Mustika Romo yang artinya orang tua atau bapak yang secara fungsionil bermakna menjadi suatu panutan dalam berkarya kerajinan perak dan emas yang berstandar internasional dan berlandaskan dengan kaidah Tri Hita Karana. UD Romo Jewelry Manufacture ini berfokus pada eksport dimana 
sebagian besar dari hasil produksi dieksport ke Amerika sebanyak 60\%, ke Eropa sebanyak 15\%, Australia sebanyak 15\%, kemudian Asia dan lokal sebanyak $10 \%$.

Berdasarkan hasil wawancara dengan salah satu karyawan, UD Romo Jewelry Manufacture memiliki desain sendiri pada produk-produknya baik untuk dijual maupun sebagai pajangan saat mengikuti pameran-pameran. Namun sebagian besar konsumen yang ingin membeli perhiasan emas ataupun perak pada UD Romo Jewelry Manufacture membawa desain sendiri sesuai dengan keinginan konsumen dan selanjutnya di proses oleh perusahaan. Perusahaan melakukan proteksi terhadap desain yang diberikan oleh konsumen dan tidak menggunakan atau menjual desain tersebut kepada konsumen lain sehingga hal tersebut berdampak menjadi penghalang pada karyawan UD Romo Jewelry Manufacture untuk menampilkan perilaku inovatif dalam menginovasi produk-produk mereka. Sebagai industri kerajinan tentunya usaha tersebut memerlukan sumber daya manusia yang terampil dan memiliki perilaku inovatif yang tinggi agar produkproduk yang dihasilkan mampu bersaing dengan produk-produk pesaing.

Tabel 1.

Hasil Pra Survei Perilaku Inovatif karyawan UD Romo Jewelry Manufacture

\begin{tabular}{llcc}
\hline No & \multicolumn{1}{c}{ Pernyataan } & Ya & Tidak \\
\hline 1 & $\begin{array}{l}\text { Saya terlibat dalam menghasilkan ide untuk } \\
\text { memperbaiki layanan }\end{array}$ & 7 & 3 \\
2 & $\begin{array}{l}\text { Saya terlibat dalam menghasilkan ide untuk } \\
\text { menciptakan sesuatu yang baru }\end{array}$ & 2 & 8 \\
3 & $\begin{array}{l}\text { Saya melibatkan sekumpulan orang untuk } \\
\text { mengumpulkan ide-ide yang telah ada }\end{array}$ & 6 & 4 \\
4 & Saya melakukan evaluasi terhadap ide-ide tersebut & 4 & 6 \\
5 & Saya mengembangkan ide-ide yang telah terkumpul & 7 & 3 \\
6 & Saya mengimplementasikan ide-ide tersebut & 8 & 2 \\
\hline & $\quad$ Jumlah (\%) & 56,67 & 43,33 \\
\hline
\end{tabular}

Sumber: UD Romo Jewelry Manufacture, 2018 
I Gusti Ayu Sastria Taradita, Pengaruh Pemberdayaan Psikologis...

Berdasarkan Tabel 1 dapat dilihat bahwa hasil dari pra survei yang dilakukan kepada 10 orang karyawan UD Romo Jewelry Manufacture mengenai perilaku inovatif dapat diketahui bahwa terdapat 7 responden ikut terlibat dalam menghasilkan ide untuk memperbaiki layanan, sedangkan 3 responden tidak ikut terlibat dalam menghasilkan ide dalam memperbaiki layanan. Kemudian, terdapat 2 responden yang turut serta dalam menghasilkan ide untuk menciptakan sesuatu yang baru, sedangkan 8 responden tidak ikut terlibat dalam menghasilkan ide untuk menciptakan hal baru. Selanjutnya, terdapat 6 responden yang melibatkan sekumpulan orang untuk mengumpulkan ide-ide yang telah ada, sedangkan 4 responden lainnya tidak melibatkan sekumpulan orang untuk mengumpulkan ideide yang telah ada.

Lalu, terdapat 4 responden yang melakukan evaluasi terhadap ide-ide tersebut, sedangkan 6 responden lainnya tidak melakukan evaluasi. Kemudian, 7 responden mengatakan ikut serta dalam mengembangkan ide-ide yang telah terkumpul, sedangkan 3 responden lainnya tidak ikut serta dalam mengembangkan ide-ide yang telah terkumpul. Selanjutnya, 8 responden menyatakan telah mengimplementasikan ide-ide yang ada, sedangkan 2 responden menyatakan belum mampu untuk mengimplementasikan ide-ide yang telah terkumpul. Berdasarkan hasil pra riset tersebut dapat disimpulkan bahwa perilaku inovatif pada karyawan UD Romo Jewelry Manufacture ada atau cukup baik namun masih belum maksimal.

Menurut beberapa ahli pemberdayaan psikologis dapat mempengaruhi perilaku inovatif karyawan. Pemberdayaan psikologis dianggap penting sebagai 
salah satu tindakan motivasi terhadap karyawan agar dapat melakukan pekerjaan seefektif mungkin (Ariyanti, 2015). Pemberdayaan psikologis dikatakan dapat memfasilitasi karyawan untuk memiliki kekuatan mengenai strategi, administrasi atau pelaksanaan, mereka dapat mengubah atau memengaruhi pelaksanaan tugas dan dapat mencoba untuk menambahkan solusi yang baru dan berguna untuk pemecahan masalah, sehingga, daya tidak kondusif untuk menampilkan tingkat perilaku inovatif yang lebih tinggi (Luohet al.,2013). Sinha et al. (2016) menemukan bahwa pemberdayaan psikologis secara positif mempengaruhi perilaku inovatif pada karyawan. Menurut Yildiz et al. (2017) jika suatu perusahaan memberi perhatian lebih pada pemberdayakan karyawan, maka hal tersebut akan memicu perilaku inovatif pada karyawan.

Rahmasari (2011) menyatakan pemberdayaan psikologis merupakan suatu konsep psikologis dan memiliki 4 dimensi utama yang membentuknya yaitu meaning, perceived impact, competence, dan self-determination. Keempat dimensi tersebut tergabung membentuk keseluruhan konstruk pemberdayaan psikologis, atau dengan kata lain, apabila salah satu dimensi tidak ada, maka tingkat pemberdayaan yang diperoleh juga tidak maksimal. Pemberdayaan berarti memberikan kekuatan, partisipasi dalam pengambilan keputusan, menerima informasi yang tepat, otonomi, kreativitas dan inovasi dalam pekerjaan, memiliki pengetahuan dan keterampilan yang diperlukan dan menerima tanggung jawab (Nikpour, 2018). Menurut Jamal dan Ali (2017) pemberdayaan psikologis membuat karyawan memiliki persepsi tentang pentingnya pekerjaannya, 
I Gusti Ayu Sastria Taradita, Pengaruh Pemberdayaan Psikologis...

kemanjuran diri, kemandirian dan efeknya pada pekerjaan, yang memberinya perasaan kontrol tentang tingkah laku inovatif.

Menurut Spreitzer (1995) pemberdayaan psikologis adalah pengalaman subjektif individu tentang pemberdayaan berdasarkan kognisi tentang dirinya sendiri dalam kaitannya dengan peran kerjanya dan ditandai sebagai keadaan psikologis empat dimensi yang terdiri dari makna, kompetensi, penentuan nasib sendiri dan dampak. Pernyataan tersebut didukung oleh Schermuly et al. (2016) yang menyatakan bahwa pemberdayaan psikologis terdiri dari beberapa peran persepsi yaitu kompetensi, makna, penentuan nasib sendiri, dan dampak terhadap pekerjaan. Dampak dari keempat kognisi tersebut mengacu pada sejauh mana seorang karyawan dapat mempengaruhi hasil kerja dan melalui hasil ini menciptakan perbedaan dalam organisasi (Akram et al., 2015).

Faktor lain yang dapat menumbuhkan perilaku inovatif pada karyawan ialah budaya organisasi. Budaya yang ada di suatu organisasi sangat besar pengaruhnya terhadap pembentukan pribadi seseorang, karena budaya organisasi menyokong tumbuhnya kreativitas sehingga menumbuhkan perilaku inovatif dari anggota organisasi tersebut (Parashakti, 2016). Budaya organisasi adalah variabel yang sangat penting bagi setiap organisasi untuk membangun perilaku yang inovatif dalam konteks pencapaian kinerja organisasi, dimana perilaku kerja yang positif dalam bentuk inovasi menjadi bagian yang penting untuk mempersiapkan kemampuan daya saing (Prayudhayanti, 2014). Eskiler et al. (2016) mengatakan budaya organisasi mendukung inovasi dalam pertumbuhan perilaku inovatif karyawan. 
Suatu budaya dapat mendukung keterkaitan antara adopsi teknologi dan pertumbuhan organisasi yang bisa menjadi faktor penentu keberhasilan strategi pertumbuhan organisasi dan memainkan peran penting dalam menentukan keberhasilan atau kegagalan organisasi (Qazi et al., 2017). Menurut Sihotang dan Zebedeus (2013) budaya organisasi merupakan perilaku budaya individu yang bekerja secara bersama-sama untuk tujuan organisasi sehingga setiap individu atau karyawan dalam organisasi perlu memahami kepentingan organisasi secara keseluruhan untuk menciptakan komitmen pribadi dalam mengembangkan organisasi yang maju, unggul dan memiliki standar kualitas tinggi, bermanfaat, dan kerja keras. Budaya organisasi merupakan sejumlah pemahaman penting, seperti norma, sikap, dan keyakinan, yang dimiliki bersama oleh anggota organisasi (Fauzi et al., 2016). Budaya organisasi merupakan sebagai suatu pola dari asumsi-asumsi dasar yang ditemukan, diciptakan atau dikembangkan oleh suatu kelompok tertentu dengan maksud agar organisasi bisa mengatasi, menanggulangi permasalahan yang timbul akibat adaptasi eksternal dan integritas internal yang sudah berjalan dengan cukup baik sehingga perlu diajarkan dan diterapkan kepada anggota-anggota baru sebagai cara yang benar untuk memahami, memikirkan dan merasakan bagian dari suatu organisasi (Novziransyah, 2017). Budaya organisasi merupakan pengendali dan arah dalam membentuk sikap dan perilaku manusia yang melibatkan diri dalam suatu kegiatan organisasi, secara individu maupun kelompok, pegawai tidak akan terlepas dengan budaya organisasi (Djuremi et al., 2016). Cao et al. (2015) mempersepsikan budaya organisasi sebagai sebuah pola asumsi dasar bersama 
I Gusti Ayu Sastria Taradita, Pengaruh Pemberdayaan Psikologis...

yang dipelajari oleh suatu kelompok ketika memecahkan masalah adaptasi eksternal sehingga yang telah bekerja cukup baik dianggap valid dan oleh karena itu diajarkan kepada anggota baru sebagai cara yang benar untuk memahami, berpikir, dan merasa sebagai bagian dari organisasi itu.

Penelitian ini merupakan replikasi dari penelitian sebelumnya yang dilakukan oleh Shruti Sinha (2016) yang secara empiris menyelidiki hubungan budaya organisasi, perilaku inovatif dan sikap kerja yang terkait dalam peran pemberdayaan psikologis. Sedangkan, penelitian ini secara empiris mencoba untuk menyelidiki pengaruh pemberdayaan psikologis dan budaya organisasi terhadap perilaku inovatif.

Mendorong karyawan untuk menampilkan perilaku kerja inovatif menjadi salah satu pilihan atau cara bagi organisasi untuk menjadi lebih inovatif dan sukses (Afsar dan Badir, 2016). Perilaku kerja inovatif didefinisikan sebagai bentuk perilaku yang bertujuan mencapai inisiasi dan pengenalan suatu ide, proses, prosedur maupun produk baru yang berguna bagi organisas (Wardhani dan Gulo, 2017). Sedangkan menurut Novianti dan Nurtjahjanti (2018) perilaku inovatif adalah keseluruhan tindakan individu yang mengarah pada pemunculan, pengenalan, dan penerapan dari sesuatu yang baru guna memberi keuntungan di seluruh tingkat organisasi.

Perilaku inovatif juga dapat diartikan sebagai keseluruhan tindakan individu yang mengarah pada pemunculan, pengenalan, dan penerapan dari sesuatu yang baru dan menguntungkan bagi organisasi (Logahan et al., 2014). Menurut Aditya dan Ardana (2016) perilaku kerja inovatif merupakan perilaku individu atau 
anggota organisasi yang memperkenalkan ide-ide untuk kemajuan organisasi/perusahaan tempat mereka bekerja. Prayudhayanti (2014) berpendapat bahwa perilaku inovatif tidak dipengaruhi oleh faktor bawaan ataupun internal, namun perilaku inovatif dalam bekerja sering muncul ketika seorang karyawan menghadapi tantangan dalam pekerjaannya dan juga ketika mendapat kewenangan yang luas dalam melaksanakan tugas dan tanggung jawabnya.

Pemberdayaan psikologis merupakan pengalaman subjektif individu tentang pemberdayaan berdasarkan kognisi tentang dirinya sendiri dalam kaitannya dengan peran kerjanya dan ditandai sebagai keadaan psikologis empat dimensi yang terdiri dari makna, kompetensi, penentuan nasib sendiri dan dampak (Spreitzer, 1995). Pendapat tersebut didukung oleh Musadieq et al. (2016) yang menyatakan bahwa pemberdayaan juga dipahami sebagai sebuah konstruk multidimensional yang terdiri dari empat kognisi dimana kognisi-kognisi ini mencerminkan bagaimana orientasi seorang individu terhadap pekerjaannya, keempat kognisi itu adalah makna, kompetensi, penentuan nasib sendiri dan dampak.Menurut Sukrajap (2016) pemberdayaan psikologis memiliki tujuan untuk memastikan bahwa keputusan yang efektif tidak hanya dibuat oleh karyawan, namun juga mempunyai efek karyawan merasa bertanggung jawab terhadap keputusan tersebut. Hal tersebut didukung oleh Widiasih (2017) bahwa karyawan yang diberdayakan akan percaya pada diri mereka dan pekerjaan yang mereka lakukan sehingga mereka akan lebih terlibat.

Mohammad Vali dan Mehrdad (2013) menyatakan bahwa pemberdayaan merupakan bagian dalam bidang psikologi, dimana pemberdayaan psikologis 
I Gusti Ayu Sastria Taradita, Pengaruh Pemberdayaan Psikologis...

diartikan sebagai motivasi yang mendominasi individu yang diekspresikan dengan upaya individu untuk mendominasi dunia mereka dan pemberdayaan dinyatakan termasuk dalam kekuatan kerja yang memberikan fleksibilitas dan lebih banyak kebebasan untuk mengambil keputusan dalam bekerja. Menurut Armanu dan Mandayanti (2012) karyawan yang diperdayakan secara psikologis melihat pekerjaan mereka sebagai sesuatu yang dapat dibentuk oleh aktivitas mereka sendiri. Menurut Yildiz et al.(2017) jika suatu perusahaan memberi perhatian lebih pada kesejahteraan karyawan dan memberdayakan karyawan, maka hal tersebut akan memicu perilaku inovatif pada karyawan. Pemberdayaan psikologis memfasilitasi kepercayaan dalam suatu organisasi yang secara positif mempengaruhi perilaku inovatif pada organisasi itu sendiri (Marane, 2012). Peneitian tersebut didukung oleh Sinha et al.(2016) yang menemukan bahwa pemberdayaan psikologis secara positif mempengaruhi perilaku inovatif pada karyawan.

Sinha et al. (2016) mengemukakan bahwa pemberdayaan psikologis secara positif mempengaruhi perilaku inovatif pada karyawan. Marane (2012) menyatakan bahwaperilaku inovatif dalam manajer yang bekerja di sektor manufaktur di Irak menemukan bahwa pemberdayaan psikologis memfasilitasi kepercayaan dalam suatu organisasi yang secara positif mempengaruhi perilaku inovatif. Suatu perusahaan yang memberi perhatian lebih pada pemberdayaaan karyawan, akan memicu tumbuhnya perilaku inovatif pada karyawan (Yildiz et al.,2017). Menurut Amalia dan Wulansari (2017) karyawan yang merasa diberdayakan oleh organisasi seharusnya akan lebih dapat memberikan perilaku 
kerja yang positif dan inovatif. Berdasarkan uraian penelitian diatas, maka dapat disimpulkan hipotesis sebagai berikut :

$\mathrm{H}_{1}$ : Pemberdayaan psikologis berpengaruh positif signifikan terhadap perilaku inovatif.

Parashakti (2016) mengungkapkan bahwa budaya yang ada di suatu organisasi sangat besar pengaruhnya terhadap pembentukan pribadi seseorang karena budaya organisasi menyokong tumbuhnya kreativitas orang-orang khususnya yang berada di dalam organisasi tersebut sehingga menumbuhkan perilaku inovatif. Prayudhayanti (2014) dalam penelitiannya menyatakan budaya organisasi adalah variabel yang sangat penting bagi setiap organisasi untuk menumbuhkan perilaku kerja yang inovatif dalam konteks pencapaian kinerja organisasi, karena perilaku kerja inovatif merupakan hal yang sangat penting untuk mempersiapkan perusahaan bersaing dengan organisasi lainnya. MenurutEskiler, et al (2016) budaya organisasi berpengaruh positif dalam pertumbuhan perilaku inovatif karyawan. Dalam penelitiannya Martins dan Terblanche (2003) menyatakan terdapat 2 cara budaya organisasi dalam mempengaruhi perilaku inovatif, pertama terjadinya proses sosialisasi individu dimana mereka belajar bagaimana bertindak dan berperilaku, kedua adalah dimana budaya mempengaruhi perilaku dengan nilai dasar, kepercayaan, dan asumsi yang mencerminkan struktur, kebijakan, konsep manajemen, dan prosedur organisasi. Berdasarkan uraian penelitian diatas, maka dapat disimpulkan hipotesis sebagai berikut :

$\mathrm{H}_{2}$ : Budaya organisasi berpengaruh positif signifikan terhadap perilaku inovatif. 


\section{METODE PENELITIAN}

Penelitian ini dilakukan pada sektor industri UD Romo Jewelry Manufacture yang berlokasi di Jalan Raya Celuk No. 42, Desa Celuk, Kecamatan Gianyar, Provinsi Bali. Adapun alasan pemilihan lokasi ini karena adanya permasalahan mengenai perilaku inovatif.

Karakteristik populasi dalam penelitian ini adalah seluruh karyawan UD Romo Jewelry Manufacture yang berjumlah 72 orang. Metode sampling yang digunakan pada penelitian ini adalah non probabilitas sampling dengan jenis teknik sampling jenuh.

Penelitian ini menggunakan metode analisis regresi linear berganda untuk menjelaskan pengaruh variabel bebas (independen) dengan variabel terikat (dependen). Adapun model regresi linear berganda yang dapat dijabarkan dengan menggunakan persamaan sebagai berikut:

$$
\mathrm{Y}=\alpha+\beta_{1} \mathrm{X}_{1}+\beta_{2} \mathrm{X}_{2}+\varepsilon
$$

Keterangan:

$$
\begin{array}{ll}
\alpha & =\text { Konstanta } \\
\beta_{1} \beta_{2} & =\text { Koefisien regresi } \\
\mathrm{Y} & =\text { Perilaku Inovatif } \\
\mathrm{X}_{1} & =\text { Pemberdayaan Psikologis } \\
\mathrm{X}_{2} & =\text { Budaya Organisasi } \\
\varepsilon & =\text { Error }
\end{array}
$$

Pengaruh variabel terikat (dependen) terhadap variabel bebas (independen) diuji dengan tingkat kepercayaan (Convidence interval) $95 \%$ atau $\alpha=5 \%$.

\section{HASIL DAN PEMBAHASAN}


Responden penelitian digambarkan secara umum disajikan dengan karakteristik yang dilihat dari variabel demografi yaitu, jenis kelamin, pendidikan dan usia.Berdasarkan jenis kelamin, persentase jumlah responden berjenis kelamin perempuan sebesar $50 \%$ dan persentase jumlah responden berjenis kelamin laki-laki sebesar 50\%. Jumlah responden perempuan dan laki-laki memiliki persentase yang sama.

Berdasarkan pendidikan, persentase jumlah responden dengan tingkat pendidikan SMP sebesar 36,1\%, kemudian responden dengan tingkat pendidikan SMA dengan persentase sebesar 51,4 \%, selanjutnya responden dengan tingkat pendidikan diploma memiliki persentase sebesar $2,8 \%$, kemudian responden dengan tingkat pendidikan sarjana dengan persentase sebesar 4,2 \%, dan lainnya memiliki persentase sebesar 5,6\%.

Berdasarkan usia, responden dengan rentang usia 12-16 tahun dengan persentase sebesar 2,8\%, kemudian diikuti dengan responden berusia 17-23 tahun dengan persentase sebesar 22,2 \%, selanjutnya responden dengan usia 24-29 tahun dengan persentase sebesar 33,3\%, berikutnya responden dengan usia 30-35 tahun dengan persentase sebesar 25,0 \%, dan responden yang berusia $>36$ tahun dengan persentase sebesar $16,7 \%$.

Uji Validitas dilakukan dengan mengkorelasikan antara skor faktor dan skor total. Apabila korelasi setiap faktor tersebut bernilai positif $(\mathrm{r}>0,3)$, maka instrumen penelitian tersebut dapat dikatakan valid. Instrumen yang valid dapat digunakan untuk mengukur apa yang seharusnya diukur. Seluruh koefisien korelasi dari indikator variabel yang diuji nilainya lebih besar dari $0,30(\mathrm{r}>0,3)$. 
I Gusti Ayu Sastria Taradita, Pengaruh Pemberdayaan Psikologis...

Hal tersebut menunjukkan bahwa seluruh indikator yang terdapat pada penelitian ini terbukti valid, sebagaimana disajikan dalam Tabel 2.

Tabel 2.

Hasil Uji Validitas

\begin{tabular}{llccc}
\hline No & Variabel & $\begin{array}{c}\text { Item } \\
\text { Pernyataan }\end{array}$ & $\begin{array}{c}\text { Korelasi Item } \\
\text { Pernyataan }\end{array}$ & Keterangan \\
\hline 1 & Pemberdayaan Psikologis $\left(\mathrm{X}_{1}\right)$ & $\mathrm{X}_{1.1}$ & 0,743 & Valid \\
& & $\mathrm{X}_{1.2}$ & 0,859 & Valid \\
& & $\mathrm{X}_{1.3}$ & 0,736 & Valid \\
2 & \multirow{2}{*}{ Budaya Organisasi $\left(\mathrm{X}_{2}\right)$} & $\mathrm{X}_{1.9}$ & 0,864 & Valid \\
& & $\mathrm{X}_{2.1}$ & 0,938 & Valid \\
& & $\mathrm{X}_{2.4}$ & 0,871 & Valid \\
& & $\mathrm{X}_{2.3}$ & 0,929 & Valid \\
3 & Perilaku Inovatif $(\mathrm{Y})$ & $\mathrm{X}_{2.9}$ & 0,886 & Valid \\
& & $\mathrm{Y}_{1}$ & 0,951 & Valid \\
& & $\mathrm{Y}_{2 .}$ & 0,984 & Valid \\
& & $\mathrm{Y}_{3}$ & 0,961 & Valid \\
\hline
\end{tabular}

Sumber :Data diolah, 2018

Tabel 2 menunjukkan bahwa instrumen-instrumen pada setiap variabel dalam penelitian ini memiliki skor total diatas 0,3 . Hasil uji validitas dari 3 variabel yang diteliti menghasilkan korelasi yang terkecil adalah 0,736 dan korelasi yang terbesar adalah 0,984. Hasil uji validitas yang dilakukan dengan kuesioner dalam penelitian ini adalah valid sehingga digunakan dalam penelitian ini.

Uji reliabilitas digunakan untuk mengukur konsistensi suatu variabel pada penelitian. Apabila suatu alat pengukur dipakai dua kali untuk mengukur gejala yang sama dan hasil pengukuran yang diperoleh relatif konsisten, maka alat pengukuran tersebut reliabel. Instrumen dikatakan reliabel untuk mengukur variabel apabila memiliki nilai Cronbach Alpha $>0,60$.

Tabel 3.

Hasil Uji Reliabilitas

\begin{tabular}{clcc}
\hline No & \multicolumn{1}{c}{ Variabel } & Cronbach Alpha & Keterangan \\
\hline 1 & Pemberdayaan Psikologis $\left(\mathrm{X}_{1}\right)$ & 0,961 & Reliabel \\
2 & Budaya Organisasi $\left(\mathrm{X}_{2}\right)$ & 0,801 & Reliabel \\
3 & Perilaku Inovatif $(\mathrm{Y})$ & 0,924 & Reliabel \\
\hline
\end{tabular}


Sumber :Data diolah, 2018

Tabel 3 menunjukkan masing-masing nilai Cronbach's Alpha pada tiap instrumen tersebut lebih besar dari 0,60 (Cronbach Alpha>0,6). Hal tersebut menunjukkan bahwa semua instrumen reliabel sehingga dapat digunakan untuk melakukan penelitian.

Uji normalitas bertujuan untuk mengetahui apakah dalam residual dari model regresi yang dibuat berdistribusi normal atau tidak. Untuk menguji apakah data yang digunakan normal atau tidak dapat dilakukan dengan menggunakan uji Kolmogorov Sminarnov. Apabila koefisien Asymp. Sig. (2-tailed) lebih besar dari 0,05 maka data tersebut dikatakan berdistribusi normal.

Tabel 5.

Hasil Uji Normalitas Persamaan Regresi

\begin{tabular}{lc}
\hline & Unstandardized Residual \\
\hline $\mathrm{N}$ & 72 \\
Kolmogorov-Smirnov $Z$ & 0,701 \\
Asymp. Sig. (2-tailed) & 0,709 \\
\hline Sumber :Data diolah, 2018 &
\end{tabular}

Berdasarkan Tabel 5 dapat dilihat bahwa nilai Kolmogorov-Sminarnov (KS) sebesar 0,701, sedangkan nilai Asymp. Sig. (2-tailed) sebesar 0,709. Hasil tersebut mengindikasikan bahwa model persamaan regresi tersebut berdistribusi normal karena nilai Asymp. Sig. (2-tailed) 0,709 lebih besar dari nilai alpha 0,05.

Jika tidak ada satu pun variabel bebas yang berpengaruh signifikan terhadap nilai absolute residual atau nilai signifikansinya di atas 0,05 , maka tidak mengandung gejala heterokedastisitas.

Tabel 6.

Hasil Uji Heterokedastisitas Persamaan Regresi

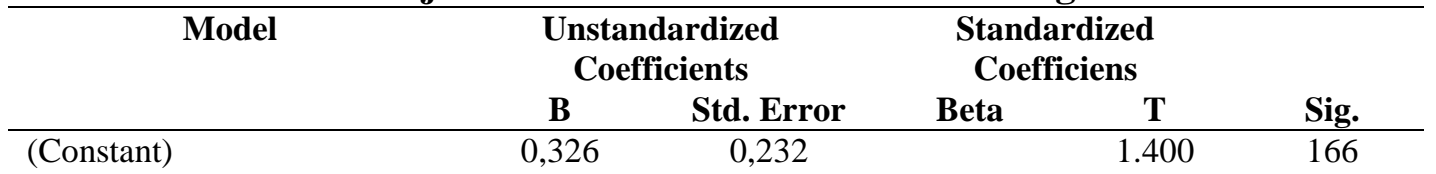


I Gusti Ayu Sastria Taradita, Pengaruh Pemberdayaan Psikologis...

$\begin{array}{llllll}\text { Pemberdayaan Psikologis } & -0,31 & 0,102 & -0,064 & -0,306 & 0,761\end{array}$

\begin{tabular}{llllll} 
Budaya Organisasi & 0,056 & 0,103 & 0,114 & 0,547 & 0,586 \\
\hline
\end{tabular}

Sumber :Data diolah, 2018

Berdasarkan Tabel 6 dapat dilihat bahwa nilai Sig. dari variabel pemberdayaan psikologis dan budaya organisasi masing-masing sebesar 0,761 dan 0,586 . Nilai tersebut lebih besar dari 0,05 yang berarti tidak terdapat pengaruh antara variabel bebas terhadap absolute residual. Dengan demikian, model yang dibuat tidak mengandung gejala heterokedastisitas.

Uji multikolinearitas bertujuan untuk menguji apakah pada model regresi ditemukan adanya korelasi antar variabel bebas. Adanya multikolinearitas dapat dilihat dari nilai tolerance atau variance inflation factor (VIF). Jika nilai tolerance lebih dari $10 \%$ atau VIF kurang dari 10, maka dikatakan tidak ada multikolinearitas.

Table 7.

Hasil Uji Multikolinearitas Persamaan Regresi

\begin{tabular}{cccc}
\hline No & Variabel & Tolerance & VIF \\
\hline 1 & Pemberdayaan Psikologis & 0,333 & 3,002 \\
2 & Budaya Organisasi & 0,333 & 3,002 \\
\hline \multicolumn{2}{l}{ Sumber: }
\end{tabular}

Berdasarkan Tabel 7 dapat dilihat bahwa nilai tolerance dan VIF dari variabel pemberdayaan psikologis dan budaya organisasi masing-masing sebesar 0,333 dan 3,002. Nilai tersebut menunjukkan bahwa nilai tolerance untuk setiap variabel lebih besar dari 10\% dan nilai VIF lebih kecil dari 10 yang berarti model persamaan regresi bebas dari multikolinearitas.

Model analisis regresi linear berganda digunakan untuk mendapat koefisien regresi yang akan menentukan apakah hipotesis yang dibuat akan diterima atau ditolak. Hasil analisis ini mengacu pada hasil pengaruh 
pemberdayaan psikologis dan budaya organisasi yang didapat dari penyebaran kuesioner pada UD Romo Jewelry Manufacture. Hasil dari pengolahan data menggunakan software SPSS 13 for windows disajikan pada Tabel 8.

Tabel 8.

Hasil Analisis Regresi Linear Berganda

\begin{tabular}{|c|c|c|c|c|c|}
\hline \multirow[t]{2}{*}{ Koefisien } & \multicolumn{2}{|c|}{$\begin{array}{l}\text { Unstandardized } \\
\text { Coefficients }\end{array}$} & \multirow{2}{*}{$\begin{array}{c}\text { Standardized } \\
\text { Coefficiens } \\
\text { Beta }\end{array}$} & \multirow[t]{2}{*}{$\mathbf{T}$} & \multirow[t]{2}{*}{ Sig. } \\
\hline & B & Std. Error & & & \\
\hline Konstanta (a) & $-0,557$ & 0,396 & & $-1,479$ & 0,163 \\
\hline $\begin{array}{l}\text { Pemberdayaan Psikologis } \\
\left(\mathrm{X}_{1}\right)\end{array}$ & 0,367 & 0,174 & 0,276 & 2,111 & 0,038 \\
\hline Budaya Organisasi $\left(\mathrm{X}_{4}\right)$ & 0,721 & 0,176 & 0,537 & 4,105 & 0,000 \\
\hline F hitung & $:$ & 53,231 & & & \\
\hline Signifikansi F & $:$ & 0,000 & & & \\
\hline R Square & : & 0,607 & & & \\
\hline Adjusted R Square & $:$ & 0,595 & & & \\
\hline
\end{tabular}

Sumber :Data diolah, 2018

Berdasarkan hasil analisis yang disajikan pada Tabel 8, maka dapat disusun persamaan regresi sebagai berikut :

$$
\begin{array}{r}
Y=\alpha-\beta_{1} X_{1}+\beta_{2} X_{2}+e_{1} \ldots \ldots \ldots \ldots \ldots \ldots . . \\
Y=-0,557+0,367 X_{1}+0,721 X_{2}+e_{1}
\end{array}
$$

Persamaan regresi berganda tersebut dapat dijelaskan bahwa apabila $\mathrm{X}_{1}$ (pemberdayaan psikologis) mengalami kenaikan sebesar 1 satuan, maka perilaku inovatif akan naik sebesar 0,367 satuan. Apabila $\mathrm{X}_{2}$ (budaya organisasi) mengalami kenaikan sebesar 1 satuan, maka perilaku inovatif akan naik sebesar 0,721 satuan. Apabila $X_{1}$ bernilai 0 dan $X_{2}$ bernilai 0 , maka perilaku inovatif besarnya sama dengan nilai konstan (-0,557 satuan). Itu berarti perilaku inovatif dipengaruhi oleh faktor lain diluar variabel bebasnya.

Nilai koefisien regresi variabel pemberdayaan psikologis bernilai positif dengan nilai signifikansi uji t kurang dari 0,05. Hal ini menunjukkan bahwa variabel pemberdayaan psikologis memiliki pengaruh positif yang signifikan 
I Gusti Ayu Sastria Taradita, Pengaruh Pemberdayaan Psikologis...

terhadap variabel perilaku inovatif. Nilai koefisien regresi variabel budaya organisasi bernilai positif dengan nilai signifikansi uji t kurang dari 0,05 . Hal ini menunjukkan bahwa variabel budaya organisasi memiliki pengaruh positif yang signifikan terhadap variabel perilaku inovatif. Besarnya pengaruh variabel bebas terhadap variabel terikat yang ditunjukkan oleh nilai determinasi total (R Square) sebesar $60,7 \%$ variasi perilaku inovatif dipengaruhi oleh variasi pemberdayaan psikologis dan budaya organisasi, sedangkan sisanya sebesar 39,3\% dijelaskan oleh faktor lain yang tidak dimasukkan ke dalam model.

Berdasarkan Tabel 8 dapat dijelaskan bahwa tingkat signifikansi $0,000<\alpha$ (0,05), sehingga $\mathrm{H}_{0}$ ditolak dan $\mathrm{H}_{1}$ diterima yang berarti bahwa pemberdayaan psikologis dan budaya organisasi berpengaruh secara simultan terhadap perilaku inovatif.

Berdasarkan Tabel 8 koefisien pemberdayaan psikologis ( $\beta 1$ ) sebesar 0,367 dengan nilai signifikansi sebesar 0,038 lebih kecil dari $\alpha(0,038<0,05)$. Hasil ini menunjukkan bahwa pemberdayaan psikologis berpengaruh signifikan terhadap perilaku inovatif di UD Romo Jewelry Manufacture. Hal ini juga dapat dibuktikan dari $t_{h} \quad$ sebesar 2,111 lebih besar dari $t_{t_{i}}$ sebesar $t_{(0,0 ; 7)}=1,994$ $\left(t_{\mathrm{h}}=2,111>\mathrm{t}_{\mathrm{t}_{\mathrm{i}}} \quad=1,994\right)$. Nilai yang menandakan arah hubungan yang positif, dengan demikian dapat dijelaskan bahwa semakin baik pemberdayaan psikologis maka perilaku inovatif akan semakin baik pula, dan sebaliknya semakin buruk pemberdayaan psikologis maka akan berdampak pada penurunan perilaku inovatif. Jadi, hipotesis dalam penelitian ini terdukung. 
Berdasarkan Tabel 8 koefisien budaya organisasi ( $\beta 2$ ) sebesar 0,721 dengan nilai signifikansi 0,000 lebih kecil dari $\alpha(0,000<0,05)$. Hasil ini menunjukkan bahwa budaya organisasi berpengaruh signifikan terhadap perilaku inovatif di UD Romo Jewelry Manufacture. Hal ini juga dapat dibuktikan dari $t_{h}$ sebesar 4,105 lebih besar dari $t_{t_{i}} \quad$ sebesar $t_{(0,0 ; 7)}=1,994\left(t_{h} \quad=4,105>t_{t_{i}}=\right.$ 1,994). Nilai yang menandakan arah hubungan yang positif, dengan demikian dapat dijelaskan bahwa semakin baik budaya organisasi maka perilaku inovatif akan semakin baik, dan sebaliknya semakin buruk budaya organisasi maka akan berdampak pada penurunan perilaku inovatif. Jadi, hipotesis kedua dalam penelitian ini terdukung.

Pengujian hipotesis pada pengaruh pemberdayaan psikologis terhadap perilaku inovatif menunjukkan bahwa pemberdayaan psikologis berpengaruh positif dan signifikan terhadap perilaku inovatif. Hasil pengujian tersebut mendukung hipotesis pertama yaitu pemberdayaan psikologis berpengaruh positif dan signifikan terhadap perilaku inovatif. Hal ini menjelaskan bahwa semakin tinggi keterlibatan perusahaan dalam memberikan pekerjaan yang berarti dan sesuai dengan kemampuan karyawan, serta semakin perusahaan dapat merasakan dampak dari karyawan maka akan semakin tinggi pula perilaku inovatif pada karyawan UD Romo Jewelry Manufacture.

Hasil penelitian ini mengembangkan penelitian sebelumnya yang dilakukan oleh Marane (2012) yang menyatakan bahwa pemberdayaan psikologis memfasilitasi kepercayaan dalam suatu organisasi yang secara positif berdampak baik terhadap perilaku inovatif. Yildiz et al. (2017) juga berpendapat bahwa suatu 
I Gusti Ayu Sastria Taradita, Pengaruh Pemberdayaan Psikologis...

perusahaan yang memberi perhatian lebih pada pemberdayaaan karyawan akan memicu tumbuhnya perilaku inovatif pada karyawan. Pendapat tersebut didukung oleh Amalia dan Wulansari (2017) yang menyatakan karyawan yang merasa diberdayakan oleh organisasi dapat lebih memberikan perilaku kerja yang inovatif.

Pengujian hipotesis pada pengaruh budaya organisasi terhadap perilaku inovatif menunjukkan bahwa budaya organisasi berpengaruh positif dan signifikan terhadap perilaku inovatif. Hasil pengujian tersebut mendukung hipotesis kedua yaitu budaya organisasi berpengaruh positif dan signifikan terhadap perilaku inovatif. Hal ini menjelaskan bahwa semakin perusahaan memperhatikan masukan konsumen, menganggap kagagalan adalah suatu proses pembelajaran, memiliki strategi dan tujuan jangka panjang, perusahaan lebih berkembang daripada perusahaan sejenis lainnya, perusahaan memiliki nilai-nilai yang harus dilaksanakan oleh seluruh karyawan maka akan semakin tinggi pula perilaku inovatif karyawan pada UD Romo Jewelry Manufacture.

Hasil penelitian ini mengembangkan penelitian sebelumnya yang dilakukan oleh Parashakti (2016) yang menyatakan bahwa budaya organisasi mempengaruhi pembentukan pribadi seseorang dan menyokong tumbuhnya kreativitas sehingga menumbuhkan perilaku inovatif seseorang. Menurut Prayudhayanti (2014) budaya organisai sangat penting bagi setiap organisasi untuk menumbuhkan perilaku kerja yang inovatif dalam konteks pencapaian kinerja organisasi. Pendapat tersebut didukung oleh Eskiler et al. (2016) yang menyatakan bahwa budaya 
organisasi mendukung inovasi dalam pertumbuhan perilaku inovatif dalam suatu organisasi.

Hasil penelitian ini menunjukkan bahwa pemberdayaan psikologis dan budaya organisasi berpengaruh secara positif dan signifikan terhadap perilaku inovatif. Hal ini menjelaskan bahwa yang dapat membantu karyawan meningkatkan perilaku inovatif adalah dengan meningkatkan pemberdayaan psikologis dan meningkatkan budaya organisasi. Ketika karyawan merasa diberdayakan secara psikologis dan merasakan nilai budaya organisasi yang kuat maka akan dapat menyokong tumbuhnya perilaku kreatif dimana dalam hal ini disebut perilaku inovatif.

Temuan penelitian ini memberikan implikasi terhadap strategi pengembangan sumber daya manusia di UD Romo Jewelry Manufacture untuk lebih memperhatikan indikator-indikator pemberdayaan psikologis dan budaya organisasi. Terutama yang harus diperhatikan pada variabel pemberdayaan psikologis adalah perusahaan dapat memberikan pekerjaan yang berarti bagi karyawannya karena memberikan pekerjaan yang berarti bagi karyawan itu sendiri memiliki nilai rata-rata tertinggi pada variabel pemberdayaan psikologis, pada variabel budaya organisasi yang harus menjadi perhatian utama yaitu perusahaan sangat memperhatikan masukan konsumen seperti pada saat konsumen memesan barang yang akan diproduksi UD Romo Jewelry Manufacture sangat memperhatikan keinginan dan masukan konsumen sehingga mendapatkan hasil yang lebih maksimal karena perusahaan memperhatikan masukan konsumen memiliki nilai rata-rata tertinggi pada variabel budaya organisasi. Sehingga 
I Gusti Ayu Sastria Taradita, Pengaruh Pemberdayaan Psikologis...

penelitian ini diharapkan dapat digunakan sebagai bahan pertimbangan perusahaan dalam meningkatkan perilaku inovatif karyawan.

Penelitian ini dilaksanakan sesuai dengan prosedur ilmiah, namun demikian masih memiliki keterbatasan yaitu faktor yang mempengaruhi perilaku inovatif dalam penelitian ini hanya terdiri dari dua variabel, yaitu pemberdayaan psikologis dan budaya organisasi, sedangkan masih banyak faktor lain yang mungkin mempengaruhi perilaku inovatif.

Adanya keterbatasan penelitian dalam menggunakan kuesioner dengan butir-butir pernyataan, terkadang pernyataan yang diberikan oleh responden tidak sepenuhnya menunjukkan keadaan yang sesungguhnya.

\section{SIMPULAN DAN SARAN}

Hasil pengujian hipotesis menunjukkan bahwa terdapat pengaruh yang positif dan signifikan pada variabel pemberdayaan psikologis terhadap perilaku inovatif pada karyawan UD Romo Jewelry Manufacture. Artinya semakin tinggi pemberdayaan psikologis yang diberikan kepada karyawan maka semakin tinggi juga perilaku inovatif karyawan UD Romo Jewelry Manufacture.

Hasil pengujian hipotesis menunjukkan bahwa terdapat pengaruh yang positif dan signifikan pada variabel budaya organisasi terhadap perilaku inovatif pada karyawan UD Romo Jewelry Manufacture. Artinya semakin tinggi budaya organisasi pada suatu perusahaan maka semakin tinggi juga perilaku inovatif karyawan UD Romo Jewelry Manufacture. 
Saran secara teoritis untuk meningkatkan perilaku inovatif karyawan pada UD Romo Jewelry Manufacture ada beberapa hal yang harus diperhatikan yaitu pemberdayaan psikologis dan budaya organisasi.

Saran secara praktis untuk mempertahankan perilaku inovatif pada karyawan, disarankan agar UD Romo Jewelry Manufacture lebih memperhatikan dan mempertimbangkan keputusan yang diberikan oleh karyawan karena indikator penentuan nasib sendiri pada item pernyataan "perusahaan selalu setuju dengan keputusan yang saya berikan" memiliki nilai rata-rata terendah pada deskripsi variabel pemberdayaan psikologis, maka dari itu diharapkan agar karyawan dapat mengembangkan kreativitasnya sehingga memicu perilaku inovatif. UD Romo Jewelry Manufacture hendaknya lebih memperhatikan apakah karyawan mampu menerapkan kesepakatan yang diterapkan bersama di perusahaan karena item pernyataan "karyawan tidak pernah menemui kesulitan untuk menerapkan kesepakatan yang ditetapkan bersama di perusahaan" memiliki nilai rata-rata terendah pada deskripsi variabel budaya organisasi.

Kepada peneliti selanjutnya agar memperluas sampel penelitian untuk memperoleh hasil yang lebih akurat, disarankan agar peneliti selanjutnya memperluas industri penelitian seperti hospitality, perbankan, kesehatan dan lain sebagainya, item pernyataan yang digunakan untuk mengukur perilaku inovatif pada penelitian selanjutnya disarankan menggunakan pernyataan yang sesuai dengan standar yang diinginkan perusahaan atau organisasi, menambahkan bahasan atau variabel mengenai pengaruh pemberdayaan psikologis dan budaya organisasi terhadap perilaku inovatif yang berguna bagi perusahaan atau 
I Gusti Ayu Sastria Taradita, Pengaruh Pemberdayaan Psikologis...

organisasi seperti kepemimpinan, kepuasan kerja, lingkungan kerja dan lain sebagainya, dan disarankan kepada peneliti selanjutnya untuk menggunakan teknik analisis yang baru agar memperoleh hasil yang lebih maksimal.

\section{REFERENSI}

Aditya, Dewa Nyoman Reza dan Komang Ardana. (2016). Pengaruh Iklim Organisasi, Kepemimpinan Transformasional, Self Effifacy terhadap Perilaku Kerja Inovatif. E-Jurnal Manajemen Unud, Vol. 5, No. 3, hal. 1801-1830.

Afsar, B. dan Yuosre Badir. (2016). The mediating role of psychological empowerment on the relationship between person-organization fit and innovative work behavior. Journal of Chinese Human Resource Management, 7 (1), pp. 5-26.

Akram, M., Dr. Hafiz Muhammad Ishaq dan Sobia Arshad. (2015). The Effect of Psychological Ownership on Relationship of Psychological Empowerment and Job Satisfaction. NUML International Journal of Business \& Management, 10(2), hal. 4-26.

Amalia, S. R., dan Wulansari, N. A. (2017). Pengaruh Person Organization Fit terhadap Perilaku Kerja Inovatif melalui Pemberdayaan Psikologis sebagai Mediasi pada Karyawan KSPPS di Semarang. Management Analysis Journal, 6 (2), hal 223-232.

Ariyanti, Y. (2015). Pengaruh Kecerdasan Emosi dan Pemberdayaan Psikologis terhadap Kinerja Karyawan. Jurnal Ekonomi dan Teknik Informatika, Vol 3, No 5, hal. 25-37.

Armanu, F. R. dan Mandayanti, N. (2012). Pengaruh Pemberdayaan Psikologis dan Komitmen Afektif terhadap Kepuasan Kerja dan Kinerja Pegawai (Studi pada Dinas Tata Kota dan Pengawasan Bangunan Kota Mataram). Jurnal Aplikasi Manajemen, Vol 10, No. 1, hal. 152-160

Bandura, A. (1989). Human Agency in Social Cognitive Theory. By the American Psychological Association, Inc. 44 (9), pp. 1175-1184

Cao, Z., Huo, B., Li, Y. dan Zhao, X. (2015). The impact of organizational culture on supply chain integration: a contingency and configuration approach. Supply Chain Management: An International Journal, 20(1), hal. 24-41

Djuremi, Hasiolan, L. B. dan Minarsih, M. M. (2016). Pengaruh Lingkungan Kerja, Budaya Organisasi dan Kepemimpinan terhadap Kinerja Pegawai 
pada Dinas Pasar Kota Semarang. Journal of Management, 2 (2), hal. 114.

Eskiler, E., Ekici, S., Soyer, F., and Sari, I. (2016). The relationship between organizational culture and innovative work behavior for sports services in tourism enterprises. Physical Culture \& Sport Studies \& Research, 69 (1), hal. 53-64.

Fauzi, M., Warso, M. M. dan Haryono, A. T. (2016). Pengaruh Budaya Organisasi dan Kepuasan Kerja terhadap Kinerja Karyawan dengan Komitmen Organisasi sebagai Variabel Intervening (Studi pada Karyawan PT. Toys Games Indonesia Semarang). Journal of Management, 2 (2), hal. 1-15.

Gaynor, G.H. (2002). Innovation by design. New York,American Management Association.

Jamal, A.H. dan Ali, H. G. (2017). Mediating Role of Psychological Empowerment between Leadership Empowerment Behavior and Job Statisfaction : A Study of Telecom Sector of Pakistan. Journal of Research Society of Pakistan, 54(1), hal. 36-44.

Kwistianus, H. dan Devie. (2015). Pengaruh Servant Leadership Terhadap Employee Empowerment, Organizational Culture, dan Competitive Advantage Pada Universitas di Surabaya. Jurnal Business Accounting Review. 3 (2), hal.191-200

Logahan, J. M., Indrajaya, A., dan Proborini, A. W. (2014). Analisis Pengaruh Perilaku Inovatif dan Self-Esteem Terhadap Organizational Citizenship Behavior Di PT Stannia Binekajasa. Binus Business Review, 5 (1), hal. 396-403.

Luoh, H. F., Tsaur, S. H. dan Tang, Y. Y. (2013). Empowering Employees : Job Standardization and Innovative Behavior. International Journal of Contemporary Hospitality Management, 26 (7), hal.1100-1117

Manoela P. (2013). Interpersonal Communication Relevance to Professional Development, in Social Systems. International Journal of Academic Research in Business and Social Sciences. 3 (4), hal.370-375

Marane, B. M. (2012). The mediating role of trust in organization on the influence of psychological empowerment on innovation behavior. European Journal of Social Sciences, 33 (1), pp.39-51.

Martins, E.C. dan Terblanche, F. (2003). Building organizational culture that stimulates creativity and innovation. European Journal of Innovation Management, 6 (1), pp. 64-74 
I Gusti Ayu Sastria Taradita, Pengaruh Pemberdayaan Psikologis...

Mohammad Vali Nazari Ali Abadi dan Mehrdad Goudarzvand Chegini. (2013). Process Of Employee Empowerment (Concepts and Dimensions). Kuwait Bab Jurnal Arab Bisnis dan Tinjauan Manajemen, 2 (11), hal. 1-9.

Musadieq, M. A., Rimawan, E., Mulyanto, A. D., dan Mahendra, A. S. (2016). Pengaruh Pemberdayaan Psikologis terhadap Efikasi Diri dan Kecerdasan Emosional. SINERGI, 20 (3), hal. 194-198.

Nikpour, A. (2018). Psychological Empowerment and Organizational Innovation: Mediating Role of Job Satisfaction and Organizational Commitment. International Journal of Organizational Leadership, 7, hal. 106-119.

Novziransyah, N. (2017). Pengaruh Budaya Organisasi Terhadap Kinerja Karyawan PT PLN (Persero) Kantor Wilayah Sumatera Utara Medan. Jurnal JUMANTIK 2(1), hal. 13-25.

Parashakti, R. D., Mochamad Rizki, dan Lisnatiawati Saragih. (2016). Pengaruh Kepemimpinan Transformasional dan Budaya Organisasi Terhadap Perilaku Inovatif Karyawan. Jurnal Manajemen Teori dan Terapan, 9 (2), hal. 81-96.

Prayudhayanti, B. N. (2014). Peningkatan Perilaku Inovatif Melalui Budaya Organisasi. EKOBIS, 15 (2), hal. 19-32

Price, J.L. (1997). Handbook of Organizational Measurement. International Journal of Manpower. 18 (4), pp. 305-558.

Qazi, S., Miralam, M. S. dan Bhalla P. (2017). Organizational culture and job satisfaction: a study Of organized retail sector. Journal of Business and Retail Management Research (JBRMR), 12 (1), hal. 215-224

Rahmasari, L. (2011). Peningkatan Motivasi Melalui Pemberdayaan Psikologis Dan Dampaknya Terhadap Kinerja Karyawan. Majalah Ilmiah INFORMATiKA, 2(1), hal. 57-67.

Schermuly, C. C., Büsch, V. dan Graßmann, C. (2016). Psychological Empowerment, Psychological and Physical Strain and the Desired Retirement Age. Personnel Review, 46(5), hal. 950-969.

Sihotang, R. B. dan Zebedeus, Z. V. (2013). Relationships between Total Quality Management Practices, Organizational Culture and Teacher's Performance: Study from Seventh Day Adventist High Schools in West Indonesia. International Research Journal of Business Studies, 6(2), hal. 105-119.

Sinha, S., Pushpendra Priyadarshi and Pankaj Kumar. (2016). Organizational Culture, Innovative Behavior and Work Related Attitude "Role of 
Psychological Empowerment". Journal of Workplace Learning, 28 (8), pp. 519-535

Spreitzer, G. M. (1995). Psychological empowerment in the workplace: Dimensions, measurement, and validation. Academy of Management Journal, 38 (5), hal. 1442-1465

Sukrajap, M. A. (2016). Pengaruh Kepemimpinan Transformasional terhadap Kepuasan Kerja dan Komitmen Organisasional dengan Dimediasi oleh Pemberdayaan Psikologis. Jurnal Psikologi, Vol. 12, No. 1, hal. 22-45

Van der Vegt, G. S., dan Janssen, O. 2003. Joint impact of interdependence and group diversity on innovation. Journal of Management, 29 (5), hal. 729751.

Wardhani, D. T. dan Gulo, Y. (2017). Pengaruh Iklim Organisasi, Kepemimpinan Transformasional dan Self Effifacy terhadap Perilaku Kerja Inovatif. Jurnal Bisnis dan Akuntansi, 19 (1a), hal. 212-217.

Widiasih, P. A. (2017). Peran Kepemimpinan Profetik dan Pemberdayaan Psikologis dalam Membangun Keterikatan Kerja Karyawan. Jurnal Ilmiah Penelitian Psikologi: Kajian Empiris \& Non-Empiris Vol. 3, No. 1, Hal. 31-41

Yildiz, B., Sumeyra Uzun dan Serdar Semih. (2017). Drivers of innovative behaviors : The moderator roles of perceived organizational support and psychological empowerment. International Journal of Organizational Leadership, 6, hal.341-360 